\title{
Environmental Monitoring and Assessment Program Western Pilot Project-Conditions of North Dakota Perennial Streams for Water Chemistry and Mercury in Fish Tissue, 2000-2003
}

\author{
Kevin C. Vining and Robert F. Lundgren
}

\section{Summary}

Sixty-five sampling sites, selected by a statistical design to represent lengths of perennial streams in North Dakota, were chosen to be sampled for water chemistry and mercury in fish tissue to establish unbiased baseline data. From the assessment of all water chemistry constituents, the percentage of stream length considered to be in poor condition was greater in the Rangeland Plains than in the Cultivated Plains. About 30 percent of perennial stream length in North Dakota was considered to be in good condition on the basis of mercury concentrations in fish tissue.

\section{Introduction}

The Environmental Monitoring and Assessment Program Western Pilot Project (EMAP-West) was undertaken in North Dakota from 2000 to 2003 to develop tools that could be used to produce unbiased estimates of ecological conditions of perennial streams in the State. The EMAP-West for North Dakota was a cooperative effort by the U.S. Environmental Protection Agency (USEPA), the U.S. Geological Survey, and the North Dakota Department of Health (NDDH). Information from the EMAP-West was used to establish baseline data that can be compared with data obtained from future monitoring and sampling activities. This fact sheet provides information about EMAP-West sampling activities in North Dakota and the conditions of streams on the basis of water chemistry and mercury in fish tissue in ecological regions of the State during 2000-2003.

\section{Ecoregions of North Dakota}

Ecological regions (ecoregions) have been loosely defined as the spatial representations of the interrelations of natural and human factors (Omernik, 1987). In North Dakota, natural vegetation, predominately prairie grass and a patchwork of forests along streams, was established on a variety of soils and topography. Since European settlement, considerable animal production, consisting mostly of cattle, and agricultural production of crops, including wheat, barley, sunflowers, canola, sugar beets, soybeans, and corn, has developed across the State. All these factors contribute to the delineation of ecoregions of North Dakota.
North Dakota is covered by four level III ecoregions as defined by Bryce and others (1998): the Northwestern Great Plains, the Northwestern Glaciated Plains, the Northern Glaciated Plains, and the Lake Agassiz Plain (fig. 1). In another ecological assessment (Stoddard and others, 2005), the USEPA indicated that North Dakota exists within two broader regions: the Cultivated Plains, a flat to gently rolling landscape that has many wetlands and streams, and the Rangeland Plains, a rolling to hilly landscape that has many wetlands but few streams in the northeast and few wetlands but many streams in the southwest (fig. 1).

\section{EMAP-West Sampling Sites}

Sampling sites were selected randomly by a USEPA statistical design (U.S. Environmental Protection Agency, 2000) to represent lengths of perennial streams in North Dakota from which unbiased baseline data would be collected. Of the 65 sites chosen for sampling (fig. 1), 63 sites were sampled for water chemistry and 49 sites were sampled for mercury in fish tissue. Samples could not be collected at the other sites because stream conditions were unacceptable or the number of fish was insufficient. Of the approximately 4,280 perennial stream miles within the State, 4,080 miles were represented in the assessment of water chemistry (2,450 miles in the Cultivated Plains and 1,630 miles in the Rangeland Plains). For North Dakota as a whole, about 3,790 miles of stream length was represented by the assessment of mercury in fish tissue. EMAP-West protocols for water chemistry and mercury in fish tissue sampling are explained in the Field Operations Manual for Wadeable Streams for EMAP-West (Peck and others, 2006). 

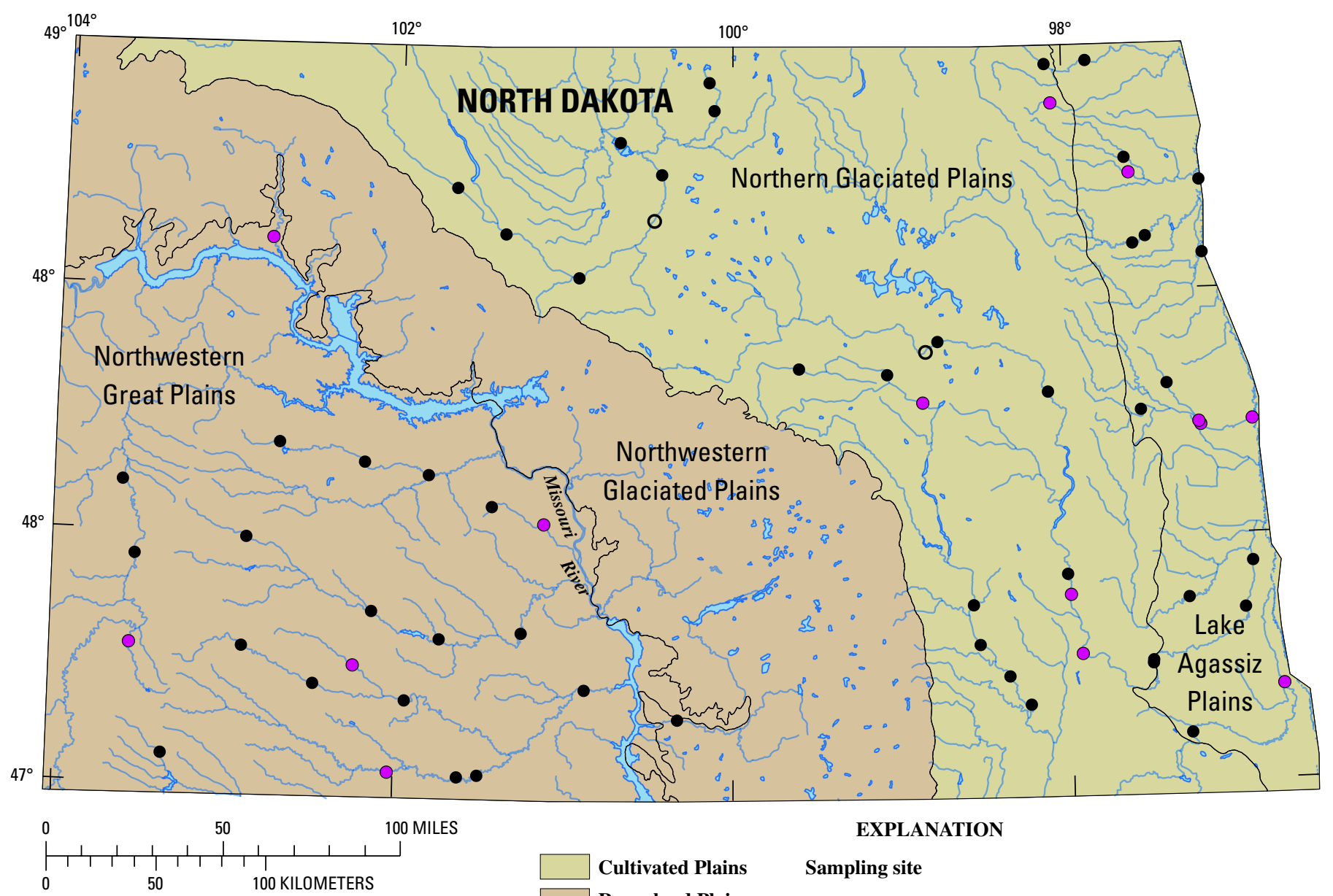

Cultivated Plains

Rangeland Plains

Figure 1. Ecoregions and EMAP-West sites used for sampling water chemistry and mercury in fish tissue in North Dakota (adapted from Tom Johnson, USEPA, written commun., 2007).

\section{EXPLANATION}

\section{Sampling site}

- Site visited; water-chemistry and fish-tissue samples collected

- Site visited; no samples collected because of unacceptable stream conditions

- Site visited; water-chemistry samples collected, but no fish-tissue samples collected because number of fish was insufficient

\section{Stream Condition Threshold Values}

The NDDH used USEPA statistical techniques on data from the analysis of water chemistry and of mercury in fish tissue to establish threshold values identifying good and poor stream conditions (Stoddard and others, 2005). Threshold values were established for the water-chemistry constituents total phosphorus, total nitrogen, and specific conductance, and for mercury in fish tissue (table 1). Threshold values for total phosphorus, total nitrogen, and mercury in fish tissue were the same as those used in an assessment of South Dakota perennial streams (Heakin and others, 2006), and the thresholds for specific conductance were the same as those used in an EMAP-West report (Stoddard and others, 2005). Thresholds for fair stream conditions were determined to fall between the thresholds for poor and good stream conditions. The threshold values for mercury in fish tissue are regional indicators selected for wildlife assessment (Lazorchak and others, 2003) and do not necessarily correspond to human health concerns.

\section{Stream Condition Assessments}

Assessments of water-chemistry conditions for perennial streams in the Cultivated Plains of North Dakota are shown in figure 2. An estimated 1,020 miles (42 percent) of stream length was considered to be in poor condition with regards to total phosphorus; 1,000 miles (41 percent) of stream length was considered to be in good condition. Approximately 148 miles ( 6 percent) and 231 miles ( 9 percent) of stream length was considered to be in poor condition on the basis of total nitrogen and specific conductance, respectively. Approximately 2,300 miles (94 percent) of stream length was considered to be in either fair or good condition on the basis of total nitrogen, and approximately 2,220 miles (91 percent) of stream length was considered to be in either fair or good condition on the basis of specific conductance.

Assessments of water-chemistry conditions for perennial streams in the Rangeland Plains of North Dakota are shown in figure 3. An estimated 639 miles (39 percent) of stream 
Table 1. Threshold water-constituent and mercury values used to determine perennial stream-condition classes of poor and good.

[>, greater than; $\mu \mathrm{g} / \mathrm{L}$, micrograms per liter; <, less than; $\mu \mathrm{S} / \mathrm{cm}$, microsiemens per centimeter; $\leq$, less than or equal to; $\mu \mathrm{g} / \mathrm{g}$, micrograms per gram]

\begin{tabular}{llllc}
\hline & \multicolumn{2}{c}{ Cultivated Plains } & Rangeland Plains \\
\hline \multicolumn{1}{c}{ Chemical stressor } & Poor condition threshold & Good condition threshold & Poor condition threshold & Good condition threshold \\
\hline Total phosphorus & $>312 \mu \mathrm{g} / \mathrm{L}$ & $<22 \mu \mathrm{g} / \mathrm{L}$ & $>138 \mu \mathrm{g} / \mathrm{L}$ & $<70 \mu \mathrm{g} / \mathrm{L}$ \\
Total nitrogen & $>2,500 \mu \mathrm{g} / \mathrm{L}$ & $<1,520 \mu \mathrm{g} / \mathrm{L}$ & $>1,190 \mu \mathrm{g} / \mathrm{L}$ & $<88 \mu \mathrm{g} / \mathrm{L}$ \\
Specific conductance & $>2,000 \mu \mathrm{S} / \mathrm{cm}$ & $\leq 1,000 \mu \mathrm{S} / \mathrm{cm}$ & $>2,000 \mu \mathrm{S} / \mathrm{cm}$ & $\leq 1,000 \mu \mathrm{S} / \mathrm{cm}$ \\
\hline & & & North Dakota (as a whole) & $\leq 0.1 \mu \mathrm{g} / \mathrm{g}$ \\
\hline
\end{tabular}

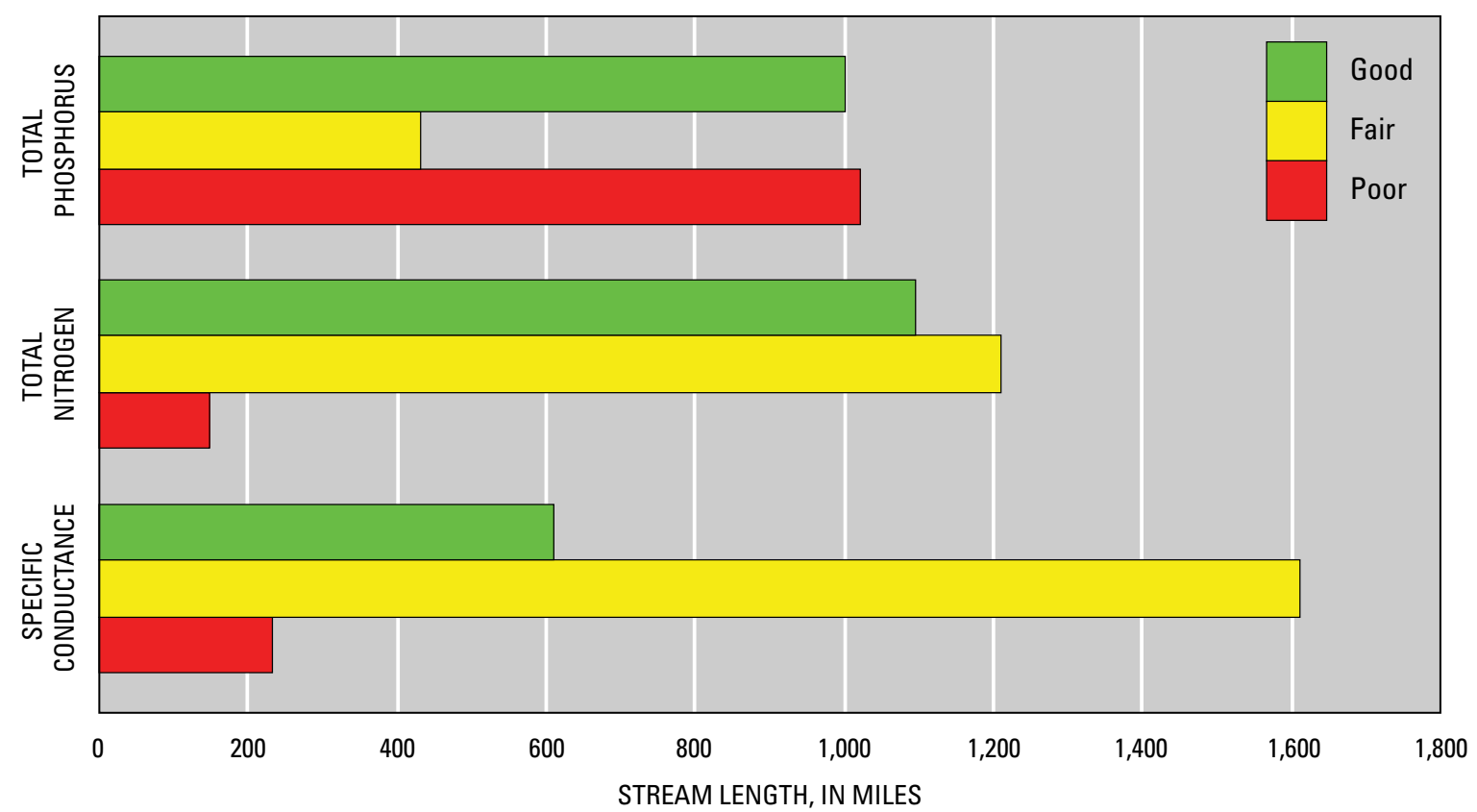

Figure 2. Stream lengths, in miles, in the Cultivated Plains that were considered to be in good, fair, and poor condition on the basis of total phosphorus, total nitrogen, and specific conductance.

length was considered to be in poor condition on the basis of total phosphorus; 774 miles (48 percent) of stream length was considered to be in good condition. An estimated 297 miles (18 percent) and 744 miles (46 percent) of stream length were considered to be in poor condition on the basis of total nitrogen and specific conductance, respectively. Approximately 1,330 miles ( 82 percent) of stream length was considered to be in either fair or good condition on the basis of total nitrogen, and about 885 miles (54 percent) of stream length was considered to be in either fair or good condition on the basis of specific conductance. From the assessments of all water-chemistry constituents, the percentage of stream length considered to be in poor condition was greater in the Rangeland Plains than in the Cultivated Plains.

Assessments of mercury in fish tissue for perennial streams in North Dakota are shown in figure 4. Results indicated about 2,140 miles (56 percent) of stream length in North Dakota had mercury concentrations greater than $0.1 \mu \mathrm{g} / \mathrm{g}$ and was considered to be in poor condition. About 1,140 miles (30 percent) of stream length in North Dakota was considered to be in good condition.

\section{References}

Bryce, S.A., Omernik, J.M., Pater, D.E., Ulmer, M., Schaar, J., Freeouf, J., Johnson, R., Kuck, P., and Azevedo, S.H., 1998, Ecoregions of North Dakota and South Dakota: Northern Prarie Wildlife Research Center, Jamestown, North Dakota, accessed August 2007 at http://www.npwrc.usgs.gov/ resource/habitat/ndsdeco/index.htm

Heakin, A.J., Neitzert, K.M., and Shearer, J.S., 2006, Summary of Environmental Monitoring and Assessment Program (EMAP) activities in South Dakota, 2000-2004: U.S. Geological Survey Scientific Investigations Report 2006-5007, $45 \mathrm{p}$.

Lazorchak, J.M., McCormick, F.H., Henry, T.R., and Herlihy, A.T., 2003, Contamination of fish in streams of the MidAtlantic Region - an approach to regional indicator selection and wildlife assessment: Environmental Toxicology and Chemistry, v. 22, p. 545-553. 


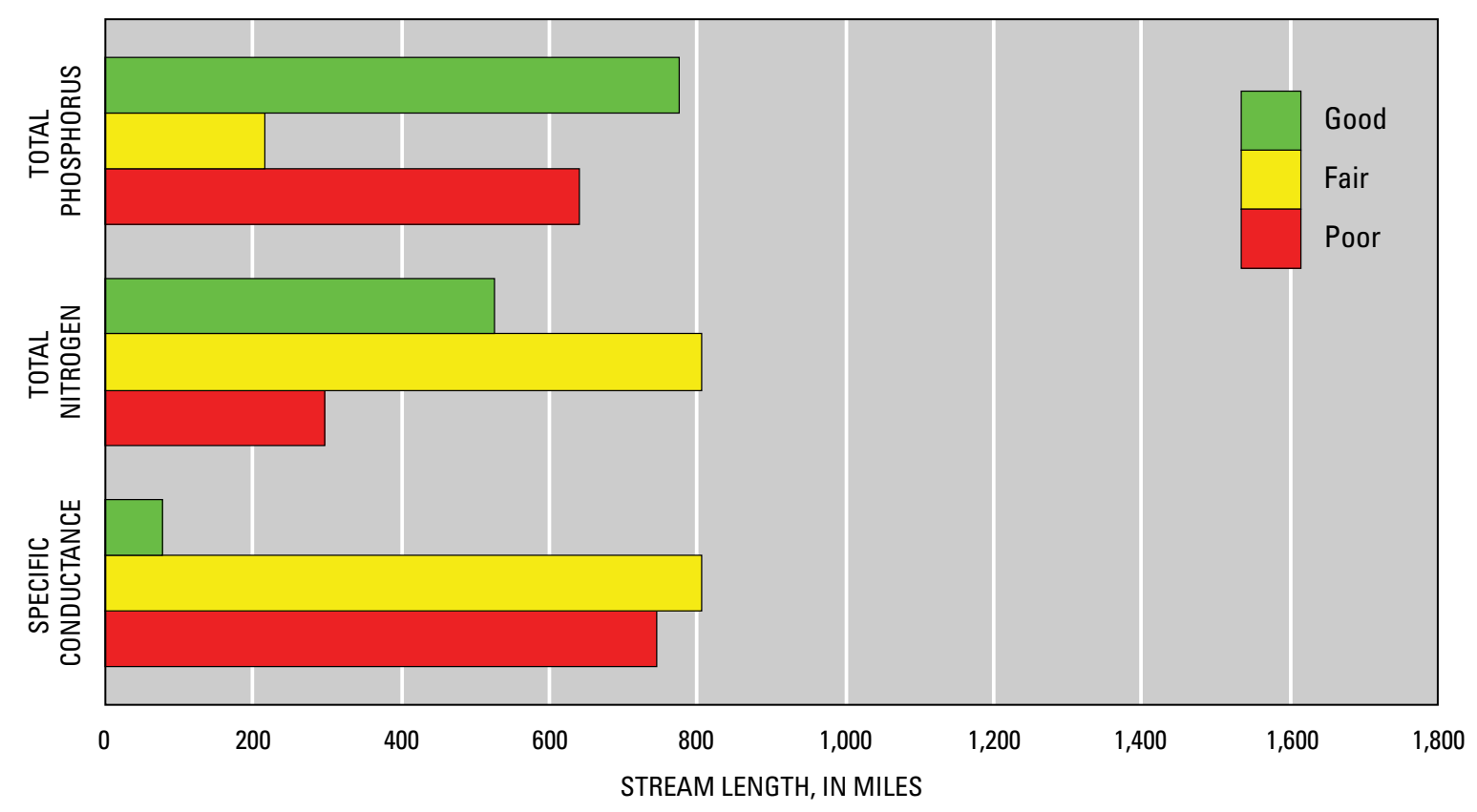

Figure 3. Stream lengths, in miles, in the Rangeland Plains that were considered to be in good, fair, and poor condition on the basis of total phosphorus, total nitrogen, and specific conductance.

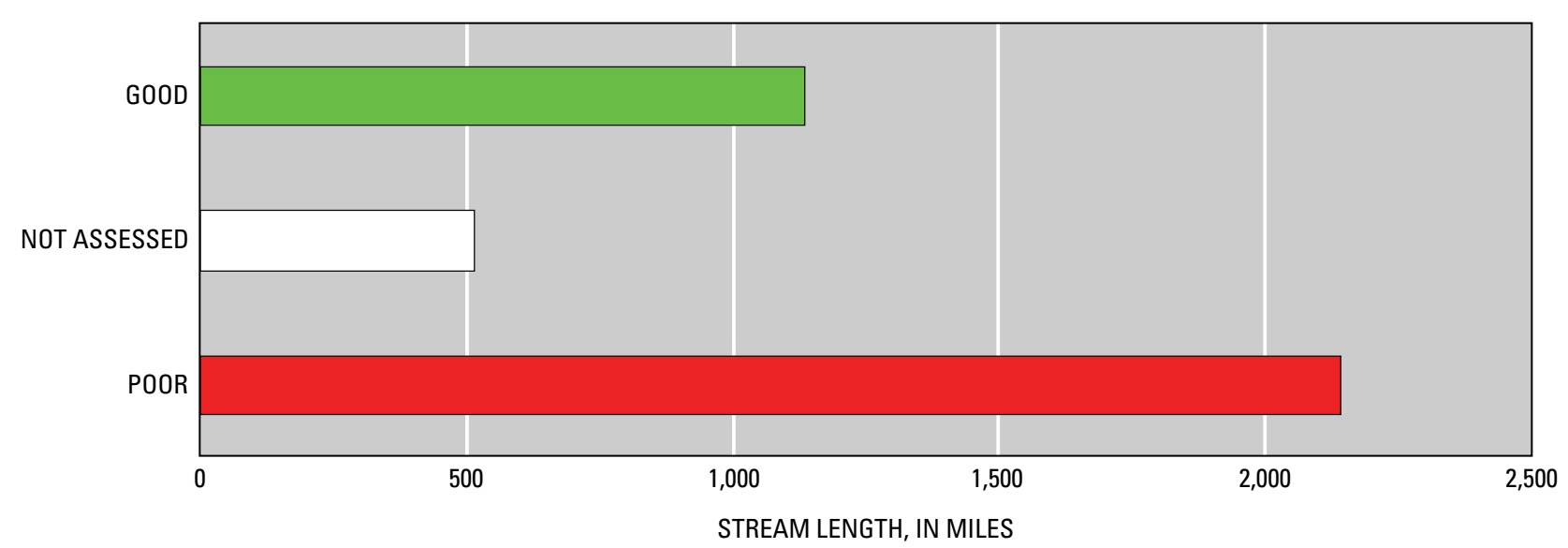

Figure 4. Stream lengths, in miles, in North Dakota as a whole that were considered to be in good and poor condition on the basis of mercury in fish tissue, and the stream length that was not assessed.

Omernik, J.M., 1987, Ecoregions of the conterminous United States: Annals of the Association of American Geographers, v. 77 , no. 1 , p. 118-125.

Peck, D.V., Herlihy, A.T., Hill, B.H., Hughes, R.M., Kaufmann, P.R., Klemm, D.J., Lazorchak, J.M., McCormick, F.H., Peterson, S.A., Ringold, P.L., Magee, T., and Cappaert, M.R., 2006, Environmental Monitoring and Assessment ProgramSurface Waters Western Pilot Study—field operations manual for wadeable streams: EPA Report EPA/620/R-06/003, U.S. Environmental Protection Agency, Office of Research and Development, Washington, D.C. [variously paged].
Stoddard, J.L., Peck, D.V., Olsen, A.R., Paulsen, S.G., Van Sickle, J., Herlihy, A.T., Kaufmann, P.R., Hughes, R.M., Whittier, T.R., Lomnicky, G., Larsen, D.P., Peterson, S.A., and Ringold, P.L., 2005, An ecological assessment of western streams and rivers: U.S. Environmental Protection Agency, Oregon State University, and Dynamac Corporation, Corvallis, Oregon, 49 p.

U.S. Environmental Protection Agency, 2000, MidAtlantic Highlands Streams Assessment: EPA Report EPA/903/R-00/015, Washington, D.C., 64 p. 